s. Marianna Ciemała ${ }^{1}$

Uniwersytet Papieski Jana Pawła II w Krakowie

\title{
Słowo Boże a życie osobiste i wspólnotowe według pierwotnej katechezy cenobickiej
}

Elementem konstytutywnym pierwszych wspólnot monastycznych pachomiańskich i bazyliańskich była codzienna relacja ze słowem Bożym. Wyrażała się ona w praktyce zapamiętywania słów Pisma, w codziennym powtarzaniu i rozważaniu słów Bożych w sercu oraz w modlitwie liturgicznej. Teksty źródłowe dla pierwotnego cenobityzmu świadczą także o tradycji biblijnych katechez wygłaszanych przez przełożonych, co stanowi rys charakterystyczny wspólnot cenobickich. Celem niniejszego artykułu jest syntetyczne omówienie pierwotnej katechezy cenobickiej, a także przedstawienie wspólnototwórczej roli słowa Bożego zawartego w tekstach normatywnych wspólnot pachomiańskich i bazyliańskich na podstawie analizy teologicznej tekstów źródłowych. W literaturze polskojęzycznej brak opracowań podejmujących bezpośrednio tę tematykę ${ }^{2}$. Bazę źródłową dla opracowania wymienionej tematyki badawczej

1 S. mgr lic. Marianna Ciemała - ze Stowarzyszenia Życia Apostolskiego „Koinonia Św. Pawła” w Kielcach. Absolwentka pedagogiki (UJK, Kielce) i teologii (UPJPII, Kraków), doktorantka przy Katedrze Patrologii na Wydziale Teologicznym Uniwersytetu Papieskiego Jana Pawła II w Krakowie; główne kierunki zainteresowań: monastycyzm okresu patrystycznego, teologia biblijna; e-mail: r.missio@complex.com.pl.

2 Zob. R. Kurek, Biblijna orientacja medytacji pachomiańskiej, „Vox Patrum” 7 (1987) t. 1213 - autor podejmuje temat zażyłości mnichów z Biblią, jednak artykuł dotyczy głównie praktyki medytacji. 
stanowią: Pachomiana Latina, Żywot grecki świętego Pachomiusza oraz Asketikon autorstwa Bazylego Wielkiego.

\section{Pierwotna katecheza cenobicka (Pachomiusz, Teodor, Bazyli Wielki)}

W koinônii ${ }^{3}$ Pachomiusza, poza modlitwą i nauką słów Pisma na pamięć, istniała także inna okazja do słuchania słowa Bożego. Przełożony rodu czy wioski pachomiańskiej wygłaszał katechezy lub nauki na temat Pisma Świętego trzy razy w tygodniu. Natomiast obowiązkiem przełożonych poszczególnych domów było głoszenie katechezy w dwa dni postne - w środy i w piątki ${ }^{4}$. Następnie, aby słowo Boże zachowało się w sercu i zostało wcielone w życie, bracia mieli rozmyślać nad otrzymaną nauką, a także wspólnie ją przedyskutować. Reguła mówi o tym wyraźnie w kilku miejscach:

Gdy rankiem w poszczególnych domach ukończą modlitwy, niech nie wracają od razu do swoich cel, lecz niech między sobą przedyskutują to, co usłyszeli w czasie katechezy przełożonego, i wówczas dopiero udadzą się do swoich cel ${ }^{5}$.

Kiedy będą przebywać $\mathrm{w}$ domu, nie godzi im się rozmawiać o sprawach świeckich, lecz niech między sobą rozważają (ruminent), co przełożony ich pouczył o Piśmie Świętym, i niech opowiedzą to, co usłyszeli i co zapamiętali'.

3 Por. R. Popowski, Wielki słownik grecko-polski Nowego Testamentu, Warszawa 1985, 342, koinwnia: „1. Wspólnota, wzajemna jedność, solidarność z kimś; 2. Wzajemna więź, oddanie względem kogoś; 3. Znak wspólnoty, dowód jedności, braterstwa, dar; 4. Udział w czymś”.

4 Por. V. Desprez, Cenobityzm pachomiański, w: Pachomiana Latina, przekł. zbiorowy, Kraków 1996, s. 55, 65 (Źródła Monastyczne, 11); Pachomius, Praecepta 20, w: Pachomiana latina, ed. A. Boon, Louvain 1932, s. 18 (Bibliothèque de la Revue d'Histoire Ecclésiastique, 7), przekł. pol.: Przykazania, tłum. A. Bober, w: Pachomiana Latina, dz. cyt., s. 132; Pachomius, Praecepta et instituta 15, w: Pachomiana latina, ed. A. Boon, dz. cyt., s. 57, przekł. pol.: Przykazania i postanowienia, tłum. M. Starowieyski, w: Pachomiana Latina, przekł. zbiorowy, dz. cyt., s. 159. Por. Pachomius, Praecepta 115, dz. cyt., s. 43n; Przykazania, dz. cyt., s. 150.

5 Pachomius, Praecepta 19, dz. cyt., s. 17n; Przykazania, dz. cyt., s. 132.

6 Pachomius, Praecepta 122, dz. cyt., s. 46; Przykazania, dz. cyt., s. 151. Por. także Pachomius, Praecepta 138, dz. cyt., s. 49; w: Przykazania, dz. cyt., s. 153: „Bezwzględnie należy przynaglić braci, żeby powtarzali między sobą to wszystko, co usłyszeli w czasie katechez, szczególnie w czasie postu, kiedy są pouczani przez swoich przełożonych". 
Żywot grecki świętego Pachomiusza zawiera przykład tego, jak po duchowym nauczaniu Pachomiusza na temat krzyża, śmierci i zmartwychwstania Chrystusa oraz o zmartwychwstaniu wierzących w Chrystusa, bracia rozważali usłyszaną naukę:

Po tych słowach ojciec nasz Pachomiusz wstał i pomodlił się wraz z braćmi, żeby zawsze pamiętali o słowach Boga dla własnego zbawienia. Każdy z nich odszedł do swego domu, rozważając to, co zapamiętał. A po odmówieniu sześciu modlitw usiedli, aby rozmawiać i wspominać to, o czym była mowa. Niemożliwe było, by ktoś powiedziałby choćby jedno bezużyteczne słowo tego świata, ale to tylko, czego się nauczyli, albo objaśnienia słów, albo o cnotliwych czynach zgodnych z wolą Bożą ${ }^{7}$.

Zachowane teksty katechez Pachomiusza są rozważaniami wychodzącymi od tekstu biblijnego, które określają następnie wspólnototwórcze postawy mnichów: zachowanie pokoju ze wszystkimi (por. Hbr 12, 14); poskramianie swoich myśli i osądzanie siebie, aby żyć pokornie „w społeczności" braci'. Katechezy Teodora, charakteryzujące się spójnością cytowanych w nich sentencji biblijnych (co było przedmiotem badań Adalberta de Vogüé), mówią o udziale w powołaniu do świętej koinônii i miłości do współtowarzyszy. Z przesłania pierwszych katechez cenobickich wyłania się apel do walki duchowej, która jest nieodłączna od miłości. Słowa i czyny braci miały służyć wzajemnemu zbudowaniu, a dla nowicjuszy miały być zbawiennym przykładem. Heinrich Bacht zwraca także uwagę na motyw naśladowania Chrystusa w katechezach Pachomiusza $^{10}$.

Poza katechezami ważną rolę spełniały także listy, kierowane przez ojców do pojedynczych osób, domów czy też wszystkich monasterów. W tym kontekście warto wspomnieć o Liście Pachomiusza,

7 Sancti Pachomii Vita graecae (Vita Prima) 58, ed. F. Halkin, Subsidia Hagiographica 19, Bruxelles 1932, s. 40, przekł. pol.: Żywot grecki świętego Pachomiusza (Vita Prima), tłum. E. Dąbrowska, w: Pachomiana Graeca, przekł. E. Dąbrowska, Kraków 2013, s. 166 (Źródła Monastyczne, 65).

8 Por. V. Desprez, Cenobityzm pachomiański, dz. cyt., s. 76.

9 Por. V. Desprez, Cenobityzm pachomiański, dz. cyt., s. 77-78, 81.

10 Por. H. Bacht, La loi du „retour aux sources”. De quelques aspects de l'idéal monastique pachômien, „Revue Mabillon” 51 (1961), s. 16. 
zaadresowanym do wszystkich monasterów z okazji corocznej Paschy, celebrowanej przez całą koinônię zgromadzoną w tym samym miejscu, a mianowicie w Phbow. List ten jest wezwaniem do godnego przygotowania się do przeżywania liturgicznych obchodów Wielkanocy. Pachomiusz posłużył się w nim tekstami biblijnymi, aby zmotywować braci do: wzajemnej służby, troski o chorych, nawrócenia, pełnienia czynów sprawiedliwości, miłości braterskiej i posłuszeństwa nakazom Bożym ${ }^{11}$.

Bazyli Wielki kładł duży nacisk na formację duchową mnichów dla dobra całej wspólnoty, a za jedyną normę życia ascetycznego uważał słowo Boże zawarte w Piśmie Świętym ${ }^{12}$. Zastanawiając się nad katechetyczną wymową Asketikonu, należy zwrócić uwagę na słowa biskupa umieszczone we Wstępie do Reguł Krótszych, skierowane do tych, „którym został powierzony dar nauczania”. Mówiąc o nich w pierwszej osobie liczby mnogiej, Bazyli włączył się do ich grona i nazwał "sługami słowa” (por. Dz 6, 4). W oparciu o tekst z 2 Tm 3, 14, naczelną zasadą ich postępowania wobec podwładnych było trwanie w nauczaniu Pisma ${ }^{13}$. Natomiast we Wstępie do Reguł Dłuższych Bazyli wezwał wszystkich do wspólnego rozważania nad tym, co każdemu jest potrzebne na drodze do doskonałości. Wspólne „dociekanie ze strony wielu razem” przynosiło bowiem, zdaniem Bazylego, więcej pożytku duchowego dla mnichów: ułatwiało im pojęcie rzeczy ukrytych, gdyż obiecany przez Chrystusa Duch Święty naucza wspólnotę uczniów i przypomina jej słowa powiedziane przez

11 Por. Pachomius, Epistula V, w: Pachomiana latina, ed. A. Boon, dz. cyt., s. 89-92, przekł. pol.: Listy Świętego Pachomiusza, tłum. W. Miliszkiewicz, w: Pachomiana Latina, przekł. zbiorowy, dz. cyt., s. 190-196.

12 Por. J. Górny, Wpływ św. Bazylego na rozwój życia monastycznego, „Vox Patrum” 2 (1982) t. 3, s. 310; J. Naumowicz, Wstęp, w: Pisma ascetyczne, t. 2: Bazyli Wielki, Reguły dłuższe, Reguły krótsze, przekł. i oprac. J. Naumowicz, Kraków 2011, s. 28-29 (Źródła Monastyczne, 6); D. Kasprzak, Eustacjański kontekst doktryny o ubóstwie monastycznym w pismach ascetycznych Bazylego Wielkiego, „Vox Patrum” 30 (2010) t. 55, s. 264n; E. A. de Mendieta, Le système cénobitique basilien comparé au système cénobitique pachômien, „Revue de l'Histoire des Religions” 152/1 (1957), s. 35.

13 Por. Basilius Magnus, Regulae brevius tractatae Prooemium 1, kol. 1080A (Patrologia Greaca, 31), przekł. pol.: Pisma ascetyczne, t. 2, dz. cyt., s. 207. Por. także - Basilius Magnus, Regulae brevius tractatae Prooemium 3, przekł. pol.: Pisma ascetyczne, t. 2, dz. cyt., s. 208-209; T. Špidlik, I. Gargano, Duchowość ojców greckich i wschodnich, tłum. J. Dembska, Kraków 1997, s. 138. 
Pana (por. J 14, 26) ${ }^{14}$. Wspólnotowe rozważanie słowa Bożego było zatem zarówno kontaktem wierzących z Duchem Świętym, jak i wspólnotowym odczytywaniem znaczenia sensu biblijnego.

\section{Wybrane postawy i tradycje budujące koinônię według tradycji pachomiańskiej}

Pachomiusz i jego następcy oraz Bazyli Wielki obficie korzystali z tekstów Pisma Świętego w formacji wspólnot, co wskazywałoby na cel życia mniszego, jakim jest życie zgodne z prawem Bożym, dojście do doskonałości na drodze wypełniania słowa Bożego ${ }^{15}$, osiągnięcie zbawienia. W pierwszym rzędzie warto zwrócić uwage na niektóre napomnienia wypływające ze słowa Bożego, skierowane do przełożonych, na których spoczywała szczególna odpowiedzialność za prowadzenie mnichów do koinônii z Bogiem i ze współbraćmi. W oczekiwaniu na powtórne przyjście Chrystusa mieli za zadanie przygotować „przed obliczem Jego wojsko ozdobione bronią" ${ }^{16}$. Dlatego Horsiesi, przywołując słowa Pisma z Listu św. Pawła do Tytusa, wzywał przełożonych, by troszcząc się o dusze braci, siebie samych we wszystkim dawali za przykład dobrych uczynków (Tt 2,7$)^{17}$. W pierwszym rzędzie każdy przełożony miał opanowywać swoje ciało, jego pożądliwości (Ef 5, 18; Rz 8, 13; Ga 5, 19) 18 $^{18}$ i troszczyć się o czystość, która jest konieczna dla pełnienia woli Bożej

14 Por. Basilius Magnus, Regulae fusius tractatae Prooemium 4, kol. 897C-D (Patrologia Greaca, 31), przekł. pol.: Pisma ascetyczne, t. 2, dz. cyt., s. 55n.

15 Zdaniem J. Naumowicza (Wstęp, dz. cyt., s. 28) Bazyli Wielki „głosi, że wypełnianie słowa Bożego - zawsze i bez wyjątku - pozostaje jedyną drogą doskonałości”; por. J. M. R. Tillard, Aux sources de l'obéissance religieuse, „Nouvelle Revue Théologique” 98 (1976) fasc. 7, s. 602 n.

16 Orsiesius, Liber Orsiesi 7, w: Pachomiana Latina, ed. A. Boon, dz. cyt., s. 112, przekł. pol.: Księga Horsiesiego, tłum. W. Miliszkiewicz, w: Pachomiana Latina, przekł. zbiorowy, dz. cyt., s. 216.

17 Por. Orsiesius, Liber Orsiesi 9, dz. cyt.; Księga Horsiesiego, dz. cyt., s. 217.

18 Por. Pachomius, Praecepta et instituta 18, dz. cyt., s. 58n; Przykazania i postanowienia, dz. cyt., s. 159n. 
(1 P 4, 2) $)^{19}$. Przełożeni mieli obowiązek okazywać posłuszeństwo wyższym przełożonym (Rz 13, 1) ${ }^{20}$, co sprzyjałoby postawie pokory wobec Boga i całej wspólnoty. Następnie zobowiązani byli unikać podstępu w czynach i myślach (Prz 22, 28) ${ }^{21}$ i zachowywać bezstronność ${ }^{22}$. Horsiesi zaś przestrzegał przed tym, by przełożeni jako źli pasterze nie doprowadzili do rozproszenia owiec, które są własnością Boga ${ }^{23}$. Dając za przykład św. Pawła (Dz 20, 20. 27. 31; 2 Kor 11, 28n), prosił przełożonych o okazywanie troski, litości i miłosierdzia powierzonej im trzodzie ${ }^{24}$.

Przykazania i Orzeczenia Pachomiusza rozpoczynają się parafrazą wybranych fragmentów Pisma:

Pełnią Prawa jest miłość (por. Rz 13, 10) dla znających czas, ponieważ już nadeszła godzina, abyśmy już ze snu powstali i bliższe jest zbawienie jak w tym czasie, w którym uwierzyliśmy; noc przeminęła, dzień się przybliżył, złóżmy więc czyny ciemności (por. Rz 13,11n), to jest spory, potwarze, nienawiści i pychę nadętego ducha (Ga 5, 20; por. 2 Kor 12, 20) ${ }^{25}$.

Można wysunąć wniosek, że mnisi pachomiańscy tymi słowami byli wezwani do nawrócenia, do porzucenia uczynków ciemności, którymi Apostoł nazwał czyny przeciw bratniej miłości, oraz do życia zgodnie z prawem miłości. Kontynuując myśl w następnym paragrafie, Pachomiusz mówił o upominaniu tych, którzy łatwo rzucają potwarze i mówią nieprawdę. Gdyby zaś nagana spotkała się z pogardą ze strony upomnianego, Pachomiusz przewidywał karę (czy też lekarstwo), jaką

19 Por. Orsiesius, Liber Orsiesi 20, dz. cyt., s. 121n; Przykazania i postanowienia, dz. cyt., s. 230.

20 Por. Pachomius, Praecepta et instituta 18, dz. cyt., s. 59; Przykazania i postanowienia, dz. cyt., s. 160.

${ }_{21}$ Por. Pachomius, Praecepta et instituta 18, dz. cyt., s. 59; Przykazania i postanowienia, dz. cyt., 160.

22 Por. Pachomius, Praecepta et instituta 18, dz. cyt., s. 59n; Przykazania i postanowienia, dz. cyt., s. 161 .

23 Por. Orsiesius, Liber Orsiesi 8, dz. cyt., s. 113; Księga Horsiesiego, dz. cyt., s. 217.

24 Por. Orsiesius, Liber Orsiesi 13, dz. cyt., s. 116n; Księga Horsiesiego, dz. cyt., s. 222.

25 Pachomius, Praecepta atque iudicia Prooemium, w: Pachomiana Latina, ed. A. Boon, dz. cyt., s. 63, przekł. pol.: Przykazania i postanowienia, tłum. M. Starowieyski, w: Pachomiana Latina, przekł. zbiorowy, dz. cyt., s. 165. 
miało być tymczasowe oddzielenie od wspólnoty braci oraz otrzymywanie uboższej racji żywnościowej ${ }^{26}$.

Dla Horsiesiego słowa Pisma Świętego stały się punktem odniesienia do sformułowania wielu różnych norm. Odwołując się do słów Jezusa z Ewangelii wg św. Jana $(\mathrm{J} 15,10)$, podkreślił wyraźnie, że postępowanie zgodne z przykazaniami jest wyrazem miłości do Boga i owocuje swoistą koinônią z Ojcem i Synem Bożym (J 14, 21. 23)27. Koinônia pachomiańska była według niego wspólnotą, która powołana została, by stać się szczególnym ludem Boga. Odpowiedzialność za tak wielki dar Horsiesi powierzył każdemu mnichowi w Zachęcie końcowej:

Odsłoniłem wszystkie te rzeczy ${ }^{28}$ po to, abyśmy rozważając życie świętych „, nie byli poruszani każdym powiewem nauki” (Ef 4,14), lecz zmagali się i ich postępowanie wzięli jako przykład dla własnego sposobu życia, byśmy się stali szczególnym ludem Boga (por. Pwt 7, 6; 14, 2; 26, 18) ${ }^{29}$.

Zważywszy więc na to, że postępowanie jednostki, zarówno pozytywne, jak i negatywne, wpływa zawsze na całą wspólnotę, następca Pachomiusza w Księdze 41 wyraził swą troskę o to, by nikt nie był przyczyną błędu drugiego ${ }^{30}$, natomiast w Księdze 43 nakazywał, by unikać złego towarzystwa, a nawet, gdy zachodzi potrzeba, przepędzić człowieka zepsutego ze zgromadzenia, by wraz z nim oddaliła się kłótnia (Prz 22, 10) ${ }^{31}$. Warto więc w tym kontekście zaakcentować jego wezwanie do nawrócenia i do prowadzenia walki przeciwko „rządcom ciemności”32:

26 Por. Pachomius, Praecepta atque iudicia Prooemium 1, dz. cyt., s. 63n; Przykazania i postanowienia, dz. cyt., s. 165.

27 Por. Orsiesius, Liber Orsiesi 44, dz. cyt., s. 137n; Ksiegga Horsiesiego, dz. cyt., s. 256.

28 Orsiesius, Liber Orsiesi 52, dz. cyt., s. 144n; Księga Horsiesiego, dz. cyt., s. 265-267 wskazuje młodym wartość rozważania pism świętych. W tym celu podaje przykłady biblijne osób, które trwały w posłuszeństwie przykazaniom.

29 Orsiesius, Liber Orsiesi 53, dz. cyt., s. 145n; Księga Horsiesiego, dz. cyt., s. 267-268. Por. A. Veilleux, La liturgie dans le cénobitisme Pachômien au quatrième siècle, Rome 1968, s. 266.

30 Por. Orsiesius, Liber Orsiesi 41, dz. cyt., s. 135; Księga Horsiesiego, dz. cyt., s. 252.

31 Por. Orsiesius, Liber Orsiesi 43, dz. cyt., s. 136n; Ksiegga Horsiesiego, dz. cyt., s. 254.

32 Zresztą, jak zauważa V. Desprez (Cenobityzm pachomiański, dz. cyt., s. 354), Testament Horsiesiego zbudowany na słowach Pisma jest obramowany dwiema egzortami, nawołującymi do nawrócenia i czujności (Księga 1-6 oraz 41-55). 
Teraz zatem, bracia, ponieważ Bóg postępuje cierpliwie i przynagla nas do nawrócenia (por. 2 P 3, 9), powstańmy z głębokiego snu (por. Rz 13, 11), „bo przeciwnik nasz diabeł jak lew ryczący szuka, kogo by pożreć. Sprzeciwiajcie mu się mocno, bo musicie przejść przez te same walki, przez które przeszli nasi poprzednicy" (1 P 5, 8n) $[\ldots]^{33}$.

Na uwagę zasługuje jednak fakt, że słowo Boże służyło nie tylko zmotywowaniu braci do podjęcia walki duchowej, ale stanowiło także skuteczną broń duchową - „miecz Ducha” (por. Ef 6, 17) ${ }^{34}$. Paralipomena służy tutaj przykładem, przytaczając zachętę Pachomiusza dotyczącą walki o to, by prowadzić życie według ducha, a nie według ciała:

Bracia, jeśli będziecie ćwiczyć się w ten sposób, wówczas naprawdę staniecie się świątynią Boga. A jeśli Bóg w was mieszka, jaka szatańska chytrość zdoła was zwieść? Słowo Boże, które w was mieszka, uczy was więcej niż tysiąc nauczycieli i daje wam mądrość przez swoją wiedzę. Czego ludzka mowa nie jest w stanie przekazać, tego uczy Prześwięty i Boży Duch ${ }^{35}$.

Horsiesi pisał o roli słowa Bożego również w kontekście troski o czystość, która jest jedną z podstawowych cnót monastycznych ${ }^{36}$.

Troska o braci, o to, by postępując za przykładem świętych, stali się współdziedzicami tej samej obietnicy ${ }^{37}$, spoczywała więc na wszystkich. Horsiesi pisał za św. Pawłem: „Wszyscy wzajemnie powinni nosić swoje brzemiona, aby wypełnić prawo Chrystusa" $(\mathrm{Ga} 6,2)^{38}$ i w różnoraki sposób wzywał do trwania w miłości ${ }^{39}$.

33 Orsiesius, Liber Orsiesi 6, dz. cyt., s. 111n; Księga Horsiesiego, dz. cyt., s. 215. Por. także Orsiesius, Liber Orsiesi 4, dz. cyt., s. 110n; Księga Horsiesiego, dz. cyt., s. 212; Orsiesius, Liber Orsiesi 25, dz. cyt., s. 126; Księga Horsiesiego, dz. cyt., s. 237.

34 Por. Liber Orsiesi 19, dz. cyt., s. 120n; Księga Horsiesiego, dz. cyt., s. 229. Zob. także Orsiesius, Liber Orsiesi 49, dz. cyt., s. 141n; Księga Horsiesiego, dz. cyt., s. 262.

35 Paralipomena 20, ed. F. Halkin, Subsidia Hagiographica 19, s. 147, przekł. pol.: Pachomiana Graeca, przekł. E. Dąbrowska, dz. cyt., s. 313.

36 Por. Orsiesius, Liber Orsiesi 20, dz. cyt., s. 121n; Księga Horsiesiego, dz. cyt., s. 230n.

37 Por. Orsiesius, Liber Orsiesi 56, dz. cyt., s. 147; Księga Horsiesiego, dz. cyt., s. 270, gdzie za przykładem św. Pawła Horsiesi powierza swoich synów Bogu i słowu Jego łaski, która może zbudować i dać dziedzictwo ze świętymi (por. Dz 20,32).

38 Por. Orsiesius, Liber Orsiesi 11, dz. cyt., s. 115n; Księga Horsiesiego, dz. cyt., s. 220.

39 Por. Orsiesius, Liber Orsiesi 47, dz. cyt., s. 140; Księga Horsiesiego, dz. cyt., s. 260. 
Nikt w monasterze nie mógł zabiegać o własne rozkosze, widząc brata w potrzebie ${ }^{40}$, wszyscy mieli okazywać sobie wzajemnie przebaczenie (Ef 4, 26; Mt 6, 12; Kol 3, 13) i łagodność, naśladując Boga samego (Ef 5, 1; Mt 5, 48;1 P 1,16 ${ }^{41}$. Wyrazem miłości miał być nie tylko jednolity sposób życia w sensie materialnym, ale przede wszystkim traktowanie siebie na równi jako braci i dzieci jednego Ojca $(\mathrm{Ml} 2,10)^{42}$. Warto w tym miejscu podać przykład opisany w Księdze 24, mówiący o swoistym byciu stróżem własnego brata, posuniętym aż do pozornej obojętności. Otóż w przypadku skarcenia któregoś z braci przez przełożonego Horsiesi polecał, aby nie przemawiać na jego korzyść i nie bronić go, gdyż takie zachowanie mogłoby zatwardzić jego serce. Taki człowiek, zdaniem Horsiesiego, sam błądząc, drugiego pociąga za sobą na drogę błędu ${ }^{43}$.

Monastyczna koinônia była również wspólnotą dóbr, wymagającą wyrzeczenia się dóbr tego świata i rezygnacji z jakiejkolwiek własności, dlatego Horsiesi wypowiedział „biada” przeciwko tym, którzy zabrali cokolwiek ze wspólnych dóbr na własny użytek, nie będąc posłuszni sło-

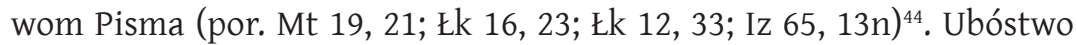
ascetyczne i wyrzeczenie się pomagały mnichowi podążać drogą naśladowania Chrystusa.

\subsection{Wybrane postawy i tradycje budujące koinônię w Asketikonie}

Dla Bazylego Wielkiego prymatem w życiu duchowym, zgodnie z Pismem, było przykazanie miłości Boga i bliźniego. Reguły dłuższe, rozpoczynające się właśnie od tego zagadnienia, wskazują na zależność przykazania miłości Boga i wszystkich pozostałych przykazań:

40 Por. Orsiesius, Liber Orsiesi 23, dz. cyt., s. 124n, Księga Horsiesiego, dz. cyt., s. 235.

41 Por. Orsiesius, Liber Orsiesi 54, dz. cyt., s. 146, Księga Horsiesiego, dz. cyt., s. 268n.

${ }_{42}$ Por. Orsiesius, Liber Orsiesi 23, dz. cyt., s. 125, Księga Horsiesiego, dz. cyt., s. 235: „Stąd też znamy to, co Pan i Zbawiciel nakazał Apostołom, mówiąc: «Przykazanie nowe daję wam, abyście się wzajemnie miłowali, jak Ja was umiłowałem, po tym poznają, że prawdziwie jesteście uczniami moimi» (J 13, 34n). Zatem musimy wzajemnie się miłować i okazywać, że prawdziwie jesteśmy sługami Pana Jezusa Chrystusa i synami Pachomiusza i uczniami wspólnego życia".

43 Por. Orsiesius, Liber Orsiesi 24, dz. cyt., s. 125n, Księga Horsiesiego, dz. cyt., s. 235n.

44 Por. Orsiesius, Liber Orsiesi 22, dz. cyt., s. 124, Księga Horsiesiego, dz. cyt., s. 234n. 
Należy jednak wiedzieć, iż (miłość do Boga) to tylko jedna z cnót, ale swą mocą obejmuje ona wszystkie przykazania i prowadzi do ich wypełnienia. „Kto bowiem Mnie miłuje”, mówi Pan, „będzie zachowywał moje przykazania” (J 14, 23)

Nieco dalej biskup Cezarei wyjaśniał, że wspomniana ścisła zależność w pierwszym rzędzie widoczna jest w odniesieniu do przykazania miłości bliźniego. Wypełnianie dwóch najważniejszych przykazań jest wzajemnie uwarunkowane ${ }^{46}$. W innym natomiast punkcie Bazyli zwracał uwagę na to, że nie można zachować żadnego przykazania bez oderwania się od trosk tego świata i uwolnienia się od wszelkich roztargnień (por. 1 Kor 7, 32n) ${ }^{47}$. Biskup wzywał też tych, którzy chcą iść za Bogiem, do wyrzeczenia się: szatana, namiętności ciała, pokrewieństwa cielesnego i przyjaźni ludzkich i wszelkiego działania sprzecznego z doskonałym wypełnieniem Ewangelii, siebie samego, bogactwa, próżnej chwały, światowego przywiązania (por. Łk 14, 33) (8. $^{4}$

Pisząc o konieczności życia wspólnego z tymi, którzy chcą podobać się Bogu, autor Asketikonu podkreślał, że „ze względu na miłość Chrystusa nie jest dozwolone, żeby każdy miał na oku tylko własne korzyści (por. 1 Kor 13, 5)”49. Zdaniem Bazylego życie wspólne jest pożyteczniejsze od życia samotnego pod wieloma względami. Jedną z korzyści, z pewnością niezrozumiałą dla niechrześcijan, jest łatwiejsze rozpoznanie swojego grzechu dzięki obecności braci, którzy mogą udzielić napomnienia oraz

45 Basilius Magnus, Regulae fusius tractatae 2, dz. cyt., kol. 908D; Pisma ascetyczne, t. 2, dz. cyt., s. 63.

46 Basilius Magnus, Regulae fusius tractatae 3, dz. cyt., kol. 917B-C; Pisma ascetyczne, t. 2 , dz. cyt., s. 72: „Poprzez pierwsze przykazanie (miłości Boga) jest zatem możliwe wypełnianie drugiego (miłości bliźniego), a przez drugie możliwy jest powrót do pierwszego. Kto miłuje Pana, będzie miłował również bliźniego. «Jeśli Mnie kto miłuje - powiedział Pan - będzie zachowywał moją naukę» (J 14, 15). Następnie mówi: «To jest moje przykazanie, abyście się wzajemnie miłowali, tak jak Ja was umiłowałem» (J 15, 12). A ze swej strony, kto miłuje bliźniego, wypełnia przykazanie miłości względem Boga, gdyż Bóg odbiera tę miłość jako Jemu okazaną".

47 Por. Basilius Magnus, Regulae fusius tractatae 5, dz. cyt., kol. 920B-924D; Pisma ascetyczne, t. 2, dz. cyt., s. 74-80.

48 Por. Basilius Magnus, Regulae fusius tractatae 8, dz. cyt., kol. 933D-941A; Pisma ascetyczne, t. 2, dz. cyt., s. 89-96.

49 Basilius Magnus, Regulae fusius tractatae 7.1, dz. cyt., kol. 929A; Pisma ascetyczne, t. 2, dz. cyt., s. 83. 
„łagodnie i ze współczuciem nakłonić do poprawy”. Co się zaś tyczy samotnego, jemu biada, bo gdy upadnie, nie ma drugiego, który by go podniósł (por. Koh 4,10$)^{50}$. Obowiązek napominania spoczywał w pierwszej kolejności na przełożonych, którzy powinni byli unikać pobłażliwości, trzymać się dyscypliny wspólnotowej, przestrzegając zawsze apostolskiej reguły w obcowaniu z braćmi (por. 1 Tes 2, 5n) ${ }^{51}$. Następnie braterskie upomnienie było obowiązkiem każdego, o czym traktuje między innymi Reguła dłuższa 36 oraz Reguła krótsza 3 i 4755. Brata, który szczerze się nawraca, należało z radością przyjąć do wspólnoty, według słów Jezusa (por. Łk 15, 6) Według biskupa Cezarei jedności we wspólnocie sprzyja realizacja słów Apostoła: „Wszystko niech się odbywa godnie i w należytym porządku” (por. 1 Kor 14, 40). Chodzi o zachowanie zasady działania, jaka panuje pomiędzy członkami jednego ciała (por. 1 Kor 12, 27) - każdy powinien działać stosownie do swego zadania, wiernie i gorliwie wypełniając swoje obowiązki oraz służąc braciom w sprawach, do których Bóg go przeznaczył ${ }^{54}$. Aby „z upodobaniem trwać przy Panu” (por. 1 Kor 7, 35), ćwiczyć

50 Por. Basilius Magnus, Regulae fusius tractatae 7.1, dz. cyt., kol. 929B; Pisma ascetyczne, t. 2, dz. cyt., s. 84 .

51 Por. Basilius Magnus, Regulae fusius tractatae 25.2, dz. cyt., kol. 985A; Pisma ascetyczne, t. 2, dz. cyt., s. 138: „Kto jest wolny od takich błędów, może być niezawodnym przewodnikiem, przynosząc pożytek sobie i prowadząc do zbawienia tych, którzy za nim idą. Jeśli nie ubiega się o ludzką cześć ani nie obawia się narazić grzesznikom i nie stara się być dla nich miłym i uprzejmym, lecz postępuje prawdziwie z miłości, będzie otwarcie głosił naukę w sposób nieskazitelny i szczery, i nie zafałszuje w niczym prawdy. Do niego będą się stosować słowa: «Stanęliśmy pośród was pełni skromności, jak matka troskliwie opiekująca się swoimi dziećmi. Będąc tak pełni życzliwości dla was, chcieliśmy wam dać nie tylko naukę Bożą, lecz nadto dusze nasze» (1 Tes 2, 7n)”. Por. także - Basilius Magnus, Regulae fusius tractatae 43, dz. cyt., kol. 1028A-1029B; Pisma ascetyczne, t. 2, dz. cyt., s. 179-181.

52 Por. Basilius Magnus, Regulae fusius tractatae 36, dz. cyt., kol. 1008C-D; Pisma ascetyczne, t. 2, dz. cyt., s. 161; Basilius Magnus, Regulae brevius tractatae 3, dz. cyt., kol. 1084A-B; Pisma ascetyczne, t. 2, dz. cyt., s. 242-243; Basilius Magnus, Regulae fusius tractatae 47, dz. cyt., kol. 1113A-1116B; Pisma ascetyczne, t. 2, dz. cyt., s. 276-278. Na temat upomnienia i przebaczenia - zob. Basilius Magnus, Regulae fusius tractatae 15, dz. cyt., kol. 1092C; Pisma ascetyczne, t. 2, dz. cyt., s. 252n wraz z przypisem.

53 Por. Basilius Magnus, Regulae fusius tractatae 8, dz. cyt., kol. 1088A; Pisma ascetyczne, t. 2, dz. cyt., s. 247.

54 Por. Basilius Magnus, Regulae fusius tractatae 24, dz. cyt., kol. 981D-984B; Pisma ascetyczne, t. 2, dz. cyt., s. 136-137; Basilius Magnus, Regulae fusius tractatae 34, dz. cyt., kol. 1000B-1001D; Pisma ascetyczne, t. 2, dz. cyt., s. 153-156. 
się w pobożności, zachować porządek oraz unikać zamętu czy zakłócenia życia braterskiej wspólnoty, należało dobierać stosowne rzemiosła i pra$\mathrm{ce}^{55}$. Praca miała być wykonywana jako realizacja przykazania Pana (por. Mt 25, 35. 40 $)^{56}$. Wszyscy - przełożeni i poddani - powinni byli odznaczać się pokorą. Przykład Chrystusa Pana (por. J 13, 8n) ukazuje, że:

bracia powinni przyjąć posługiwanie odnoszące się także do ciała ze strony tych, którzy w braterskiej wspólnocie są wyżej postawieni. Prawdziwa pokora zakłada bowiem, że ktoś znaczniejszy jest gotowy do służenia, a niższy nie krępuje się tym, że jest obsługiwany ${ }^{57}$.

W trosce o zachowanie przez braci niezmąconego umysłu oraz z obawy przed niepokojem i zamętem w życiu wspólnoty, Bazyli, posługując się argumentacją biblijną, określił również właściwe relacje z „krewnymi co do ciała". Podaje różne wskazania, w zależności od sytuacji oraz świata wartości reprezentowanego przez krewnych. Wobec żyjących zgodnie z wolą Bożą biskup dał następujące zalecenia:

Pismo w ogóle nie dozwala, aby w braterskiej wspólnocie mówić „moje” i „twoje”. Powiedziano bowiem: "Jeden duch i jedno serce ożywiały wszystkich wierzących. Żaden nie nazywał swoi tego, co posiadał" (Dz 4, 32). Dlatego rodzice czy rodzeństwo któregoś z braci, jeśli żyją po Bożemu, winni być traktowani we wspólnocie jako ojcowie czy krewni wszystkich. Pan mówi przecież: „Kto pełni wolę Ojca mojego, który jest w niebie, ten Mi jest bratem, siostrą i matką" (Mt 12, 50). Uważamy też, iż troska o nich należy do przełożonego braterskiej wspólnoty ${ }^{58}$.

Biskup Cezarei podjął także w swoim dziele kwestię stosownej dla chrześcijańskiego powołania mowy - przestrzegając przed: słowami bezużytecznymi (por. Mt 12, 36), czyli takimi, które nie przyczyniają się

55 Por. Basilius Magnus, Regulae fusius tractatae 38, dz. cyt., kol. 1016D-1017C; Pisma ascetyczne, t. 2, dz. cyt., s. 169n.

56 Por. Basilius Magnus, Regulae fusius tractatae 42, dz. cyt., kol. 1024D-1025B; Pisma ascetyczne, t. 2, dz. cyt., s. 177.

57 Basilius Magnus, Regulae fusius tractatae 31, dz. cyt., kol. 993B-D; Pisma ascetyczne, t. 2, dz. cyt., s. 147n; Por. Basilius Magnus, Regulae fusius tractatae 43.2, dz. cyt., kol. 1028C; Pisma ascetyczne, t. 2, dz. cyt., s. 180: o pokorze przełożonych.

58 Basilius Magnus, Regulae fusius tractatae 32, dz. cyt., kol. 996A; Pisma ascetyczne, t. 2, dz. cyt., s. 149. 
do ugruntowania wiary (por. Ef 4, 29) $)^{59}$; obelgą (por. J 9, 28) ${ }^{60}$; obmową (por. Ps 101, 5; Prz 20, 13) ${ }^{61}$; szemraniem (por. Flp 2, 14) ${ }^{62}$.

\section{Podsumowanie}

Przykłady postaw i tradycji zaczerpniętych ze słowa Bożego przez Pachomiusza czy Bazylego Wielkiego wskazują na świadome kształtowanie koinônii monastycznej według wzorca biblijnego. W tekstach pachomiańskich można odnaleźć dydaktyczne zastosowanie Pisma Świętego do religijnego formowania życia osobistego i wspólnotowego mnichów. Uczestnictwo w poszczególnych formach tego dydaktycznego słuchania i dzielenia się słowem Bożym było dla mnichów pachomiańskich obowiązkowe. Celem formacji biblijnej mnichów była lepsza praktyka zaleceń biblijnych w ich codziennym życiu. Na podstawie analizy zaleceń Asketikonu Bazylego Wielkiego można zaś stwierdzić, że ich autor w procesie formacji biblijnej mnichów w sposób szczególny podkreślał rolę przełożonych („,słudzy słowa”).

Badając teksty pachomiańskie oraz bazyliańskie pod kątem formacyjnego zastosowania Biblii we wspólnotach monastycznych, można w nich także wyróżnić liczne formy retorycznego oddziaływania na członków poszczególnych wspólnot: napomnienia skierowane do przełożonych, ekshortacje do osobistego nawrócenia, apele do porzucenia uczynków przeciw bratniej miłości, wezwania do postępowania zgodnego z przykazaniami miłości Boga i bliźniego, zachęty do budowania wspólnoty poprzez dawanie dobrego przykładu i „budującą mowę”, upominanie braterskie, wzbudzanie troski o braci, ponaglanie do wzajemnej służby,

59 Por. Basilius Magnus, Regulae brevius tractatae 23, dz. cyt., kol. 1097D-1100A; Pisma ascetyczne, t. 2, dz. cyt., s. 260n.

${ }^{60}$ Por. Basilius Magnus, Regulae fusius tractatae 24, dz. cyt., kol. 1100B; Pisma ascetyczne, t. 2, dz. cyt., s. 261.

${ }_{61}$ Por. Basilius Magnus, Regulae fusius tractatae 25, 26, 27, dz. cyt., kol. 1100C-1101A; Pisma ascetyczne, t. 2, dz. cyt., s. 262n.

62 Por. Basilius Magnus, Regulae fusius tractatae 39, dz. cyt., kol. 1108C; Pisma ascetyczne, t. 2, dz. cyt., s. 271. 
żądania walki duchowej, prośby o trwanie w obecności Boga, ponaglenia do naśladowania Boga, postulowanie wyrzeczenia się dóbr i trosk światowych, ponaglenia do zachowania porządku we wspólnocie, upomnienia o zachowanie właściwych relacji z krewnymi.

Zarówno dydaktyczne, jak i retoryczne wykorzystanie tekstu biblijnego służyło pierwszym cenobickim zakonodawcom do kształtowania ich wspólnot monastycznych według modelu koinônii. 


\section{Summary}

\section{Słowo Boże a życie osobiste i wspólnotowe według pierwotnej katechezy cenobickiej}

W artykule omówiono pierwotną katechezę cenobicką, której celem była duchowa formacja mnichów dla dobra całej wspólnoty. Prawodawstwo monastyczne sformułowało w sposób wzorcowy biblijne wymagania i wskazania dotyczące postaw cenobitów i tradycji wspólnotowych. Analiza tekstów reguł monastycznych prowadzi do wniosku, że wszystkie zalecenia i praktyczne rozstrzygnięcia płynące ze słowa Bożego służyły budowaniu wspólnego życia osób, które odpowiedziały na dar powołania do „świętej koinônii”. Charakterystyczne dla koinônii pachomiańskiej było dydaktyczne zastosowanie Pisma Świętego do formacji indywidualnej i wspólnotowej. Natomiast Asketikon Bazylego Wielkiego uwydatnia rolę przełożonych, którzy w procesie formacji biblijnej braci mieli być „sługami słowa”. Kształtowaniu koinônii według wzorca biblijnego sprzyjały również liczne formy retorycznego oddziaływania na członków poszczególnych wspólnot.

Słowa kluczowe: słowo Boże, katecheza, koinônia, formacja

The Word of God for personal and community's life according to original cenobitic catechesis

Monastic legislation has expressed in a perfect way biblical requirements and indications concerning to cenobites' attitudes and the tradition of the community. It appears, after analysing some of the texts of the monastic rules, that all of the recommendations and conclusions which come from The Word of God, have been designed to create life in the community for those people who responded to the gift of God's calling to „the holly community”. It has been significant for the Pachomian Community, that The Holy Bible has been didactically applied to the both individual and community's development. However Asketikon of Basil the Great emphasizes the role of the superiors who were to be "the servants of the word" throughout the biblical formation process. According to the biblical pattern, the community's creation favoured different forms of rhetorical influence on members of particular communities.

Keywords: the word of God, catechesis, koinônia, formation 


\section{Bibliografia}

Bacht H., La loi du „retour aux sources”. De quelques aspects de l'idéal monastique pachômien, „Revue Mabillon” 51 (1961), s. 6-25.

Basilius Magnus, Regulae brevius tractatae, k. 1052-1306 (Patrologia Greaca, 31); przekł. pol.: Pisma ascetyczne, t. 2: Bazyli Wielki, Reguły dłuższe, Reguły krótsze, przekł. i oprac. J. Naumowicz, Kraków 2011, s. 207-501 (Źródła Monastyczne, 6).

Basilius Magnus, Regulae fusius tractatae, k. 889-1052 (Patrologia Greaca, 31); przekł. pol.: Pisma ascetyczne, t. 2: Bazyli Wielki, Reguły dłuższe, Reguły krótsze, przekł. i oprac. J. Naumowicz, Kraków 2011, s. 45-203 (Źródła Monastyczne, 6).

Desprez V., Cenobityzm pachomiański, w: Pachomiana Latina, przekł. zbiorowy, Kraków 1996, s. 15-82 (Źródła Monastyczne, 11).

Górny J., Wpływ św. Bazylego na rozwój życia monastycznego, „Vox Patrum” 2 (1982) t. 3, s. 298-312.

Kasprzak D., Eustacjański kontekst doktryny o ubóstwie monastycznym w pismach ascetycznych Bazylego Wielkiego, „Vox Patrum” 30 (2010) t. 55, s. 257-273.

Kurek R., Biblijna orientacja medytacji pachomiańskiej, „Vox Patrum” 7 (1987) t. 1213, s. 247-259.

Mendieta de E. A., Le système cénobitique basilien comparé au système cénobitique pachômien, „Revue de l'Histoire des Religions” 152 (1957) nr 1, s. 31-80.

Naumowicz J., Wstęp, w: Pisma ascetyczne, t. 2: Bazyli Wielki, Reguły dłuższe, Reguły krótsze, przekł. i oprac. J. Naumowicz, Kraków 2011, s. 11-42 (Źródła Monastyczne, 6).

Orsiesius, Liber Orsiesii, ed. A. Boon, w: Pachomiana Latina, Louvain 1932, s. 107-147 (Bibliothèque de la Revue d'Histoire Ecclésiastique, 7), przekł. pol.: Ksiegga Horsiesiego, tłum. W. Miliszkiewicz, w: Pachomiana Latina, przekł. zbiorowy, Kraków 1996, s. 210273 (Źródła Monastyczne, 11).

Pachomius, Epistulae, ed. A. Boon, w: Pachomiana latina, s. 77-101 (Bibliothèque de la Revue d'Histoire Ecclésiastique, 7), przekł. pol.: Listy Świętego Pachomiusza, tłum. W. Miliszkiewicz, w: Pachomiana Latina, przekł. zbiorowy, Kraków 1996, s. 173-206 (Źródła Monastyczne, 11).

Pachomius, Praecepta atque iudicia, ed. A. Boon, w: Pachomiana latina, Louvain 1932, s. 63-70 (Bibliothèque de la Revue d'Histoire Ecclésiastique, 7), przekł. pol.: Przykazania i postanowienia, tłum. M. Starowieyski, w: Pachomiana Latina, przekł. zbiorowy, Kraków 1996, s. 165-169 (Źródła Monastyczne, 11).

Pachomius, Praecepta et instituta, ed. A. Boon, w: Pachomiana latina, Louvain 1932, s. 53-62 (Bibliothèque de la Revue d'Histoire Ecclésiastique, 7), przekł. pol.: 
Przykazania i postanowienia, tłum. M. Starowieyski, w: Pachomiana Latina, przekł. zbiorowy, Kraków 1996, s. 156-164 (Źródła Monastyczne, 11).

Pachomius, Praecepta, ed. A. Boon, w: Pachomiana latina, Louvain 1932, s. 13-52 (Bibliothèque de la Revue d'Histoire Ecclésiastique, 7), przekł. pol.: Przykazania, tłum. A. Bober, w: Pachomiana Latina, przekł. zbiorowy, Kraków 1996, s. 128-155 9 Źródła Monastyczne, 11).

Popowski R., Wielki słownik grecko-polski Nowego Testamentu, Warszawa 1985.

Sancti Pachomii Vita graecae (Vita Prima), ed. F. Halkin, Subsidia Hagiographica 19, Bruxelles 1932, s. 1-96, przekł. pol.: Żywot grecki świętego Pachomiusza (Vita Prima), tłum. E. Dąbrowska, w: Pachomiana Graeca, przekł. E. Dąbrowska, Kraków 2013, s. 117246 (Źródła Monastyczne, 65).

Špidlik T., Gargano I., Duchowość Ojców greckich i wschodnich, tłum. J. Dembska, Kraków 1997.

Tillard J.M.R., Aux sources de l'obéissance religieuse, „Nouvelle Revue Théologique” 98 (1976) fasc. 7, s. 592-626.

Veilleux A., La liturgie dans le cénobitisme Pachômien au quatrième siècle, Rome 1968. 